\title{
Aspekty ekologistycznego zarządzania ryzykiem w gospodarce magazynowej wyrobów gotowych branży FMCG
}

\author{
Dr hab. inż. Ewa Kulińska, prof. PO \\ Politechnika Opolska, Wydział Inżynierii Produkcji i Logistyki, Katedra Logistyki \\ Mgr inż. Julia Giera \\ Politechnika Opolska, Wydział Inżynierii Produkcji i Logistyki, Katedra Logistyki
}

\section{Wprowadzenie}

W ciągu ostatnich lat temat ekologii stał się nieodłącznym elementem życia ludzkiego. To właśnie społeczeństwo odpowiada za ochronę środowiska naturalnego. Powstające odpady są związane z działalnością człowieka oraz z systemem gospodarczym przedsiębiorstw. Również w obszarze logistyki temat ekologii jest istotny, w szczególności w gospodarce magazynowej.

Celem artykułu jest ukazanie ekologistycznego aspektu zarządzania ryzykiem w logistycznym procesie magazynowania wyrobów gotowych z branży Fast Moving Consumer Goods (FMCG). Połączenie aspektu ekologii i prawidłowego funkcjonowania procesu magazynowego jest konieczne dla zrównoważonego rozwoju gospodarczego. Obszar magazynowy jest obarczony licznymi czynnikami ryzyka. Niedopuszczenie do wystąpienia zakłóceń oraz ochrona środowiska naturalnego wymagają opracowania ekologistycznej procedury zarządzania ryzykiem w gospodarce magazynowej, która została ukazana w publikacji za pomocą metody IDEF.

Poprzez zastosowanie metodologii badawczej w postaci mapowania ryzyka wskazano poszczególne elementy, jakie muszą zostać wdrożone do przedsiębiorstw w celu ochrony środowiska naturalnego oraz eliminacji czynników ryzyka.

Zastosowanie odpowiednich procedur to nie tylko postępowanie zgodnie z zasadami ekologii i prawidłowego funkcjonowania procesu magazynowego, ale również realne oszczędności finansowe i zasobowe przedsiębiorstw, co jest kluczowe dla współczesnego ekologistycznego łańcucha dostaw. 


\section{Zarządzanie ryzykiem w procesie magazynowym}

Ryzyko jest nieodłącznym elementem w logistyce, a szczególnie widoczne jest w gospodarce magazynowej. Ryzyko to możliwość wystąpienia zdarzenia, które wpłynie na realizację celów organizacji. Ma ono mierzalne prawdopodobieństwo oraz skutek. Postrzegane jest głównie jako zjawisko negatywne, którego powinno się unikać ${ }^{1}$.

Zarządzanie ryzykiem w procesach logistycznych to planowanie, organizowanie, realizacja oraz kontrola przepływowej formy organizacji, tworzona w celu maksymalnego ograniczenia częstotliwości występowania czynników ryzyka, a w przypadku ich wystąpienia - minimalizacja negatywnych skutków, która polega na zmniejszeniu powstałych strat ${ }^{2}$.

W celu uzyskania efektów poprzez zarządzanie ryzykiem powinno być ono realizowane po zaznajomieniu się z czynnikami, które oddziałują na jego występowanie w procesach logistycznych.

Prawdopodobieństwo wystąpienia czynnika ryzyka w procesie magazynowym jest wysokie. Wzrasta w szczególności, gdy składujemy towary przez długi czas, występuje duża rotacja dóbr, towar jest transportowany wewnątrz magazynu oraz przekazujemy dobra z jednego magazynu do innych magazynów organizacji, włącznie z magazynami wysyłkowymi ${ }^{3}$.

Elementy, które tworzą zagrożenie dla wyrobu gotowego w procesie magazynowym, to:

- obiekty magazynowe,

- urządzenia magazynowe,

- środki transportu wewnętrznego oraz zewnętrznego,

- czynnik ludzki4.

W gospodarce magazynowej występuje kilkanaście rodzajów czynników ryzyka. Zakłócenia zostały pogrupowane na:

- proces magazynowy,

- infrastrukturę oraz wyposażenie magazynu,

- model zarządzania gospodarką magazynową.

$\mathrm{W}$ tabeli 1 przedstawiono czynniki ryzyka w procesie magazynowym.

1 E. Kulińska, Aksjologiczny wymiar zarzqdzania ryzykiem procesów logistycznych. Modele i eksperymenty ekonomiczne, Oficyna Wydawnicza Politechniki Opolskiej, Opole 2011, s. 46.

2 E. Kulińska, Parametryzacja kosztów ryzyka procesów logistycznych, Wydawnictwo PLACET, Warszawa 2015, s. 63.

3 T. Kaczmarek, Zarzadzanie ryzykiem. Ujęcie interdyscyplinarne, Wydawnictwo Difin, Warszawa 2010, s. 156-157.

4 B. Galińska, Gospodarka magazynowa, Wydawnictwo Difin, Warszawa 2016, s. 148-152. 
Poniżej wymieniono najważniejsze zagrożenia, jakie mogą wystąpić w procesie magazynowym. Poszczególne czynniki ryzyka na różnych etapach procesu magazynowego są podobne lub takie same pod względem skutku, jaki ze sobą niosą. Ułatwia to identyfikację oraz podjęcie odpowiednich kroków w celu ich eliminacji lub ograniczenia.

Tabela 1. Czynniki ryzyka w gospodarce magazynowej

\begin{tabular}{|c|c|}
\hline \multicolumn{2}{|r|}{ Czynniki ryzyka procesu magazynowego } \\
\hline \multicolumn{2}{|r|}{ Etapy procesu magazynowego } \\
\hline $\begin{array}{l}\text { Proces } \\
\text { przyjęcia }\end{array}$ & $\begin{array}{l}\text { - Przyjęcie niewłaściwego towaru na magazyn } \\
\text { - Dostawa niezamawianego towaru } \\
\text { - Przyjęcie niezgodnej ilości wyrobu } \\
\text { - Otrzymanie uszkodzonego dobra } \\
\text { - Wady ukryte produktu } \\
\text { - Uszkodzenie towaru podczas przyjęcia wyrobu do magazynu } \\
\text { - Przyjęcie produktu z niepełną lub źle wypełnioną dokumentacją } \\
\text { - Niewłaściwa identyfikacja dóbr } \\
\text { - Btędne posortowanie produktów } \\
\text { - Nieprawidtowe oznakowanie towaru } \\
\text { - Nieprawidtowe określenie terminu dostawy }\end{array}$ \\
\hline $\begin{array}{l}\text { Proces } \\
\text { sktadowania }\end{array}$ & $\begin{array}{l}\text { - Posiadanie zapasów zbędnych } \\
\text { - Zmniejszenie liczby wydań towaru z magazynu } \\
\text { - Uszkodzenie towaru podczas magazynowania } \\
\text { - Magazynowanie wyrobów w niewłaściwym miejscu } \\
\text { - Nieprawidtowe zabezpieczenie towarów składowanych }\end{array}$ \\
\hline $\begin{array}{l}\text { Proces } \\
\text { kompletacji }\end{array}$ & $\begin{array}{l}\text { - Nieprawidłowe skompletowanie partii towarów } \\
\text { - Pobranie niewłaściwego towaru } \\
\text { - Pobranie wyrobów z nieodpowiedniego miejsca składowania } \\
\text { - Nieodpowiednie zabezpieczenie wyrobu } \\
\text { - Niewykonanie kompletności zamówienia } \\
\text { - Nieprawidłowe oznakowanie jednostki ładunkowej } \\
\end{array}$ \\
\hline Proces wydań & $\begin{array}{l}\text { - Występowanie braków materiałowych } \\
\text { - Wady ukryte materiału } \\
\text { - Wydanie z magazynu nieprawidłowego towaru } \\
\text { - Wydanie z magazynu nieprawidtowej ilości towaru } \\
\text { - Pobranie towaru z nieprawidłowego miejsca na magazynie } \\
\text { - Uszkodzenie wyrobów podczas załadunku towarów na środek transportu } \\
\text { zewnętrznego } \\
\text { - Wydanie nieprawidłowo sporządzonej dokumentacji wysyłkowej }\end{array}$ \\
\hline \multicolumn{2}{|c|}{ Infrastruktura magazynu i model zarządzania gospodarką magazynową } \\
\hline $\begin{array}{l}\text { Infrastruktura } \\
\text { oraz } \\
\text { wyposażenie } \\
\text { magazynu }\end{array}$ & $\begin{array}{l}\text { - Nieodpowiednia powierzchnia składowa } \\
\text { - Brak oznakowania pól znakowania } \\
\text { - Brak pól odkładczych } \\
\text { - Brak podziału magazynu na materiały szybkiej oraz wolnej rotacji } \\
\text { - Posiadanie nieodpowiedniego sprzętu do składowania wyrobów oraz } \\
\text { zastosowanej metody składowej } \\
\text { - Lokalizacja magazynów }\end{array}$ \\
\hline
\end{tabular}


Tabela 1. (cd.)

\begin{tabular}{|l|l|}
\hline \multicolumn{2}{|c|}{ Czynniki ryzyka procesu magazynowego } \\
\hline Model & - Brak klasyfikacji materiałów \\
zarządzania & - Brak szczegółowych danych dotyczących poszczególnych zapasów \\
magpodarką & - System kontroli jakości materiałów \\
& - Kwalifikacje i doświadczenie pracowników \\
& - Niedobór pracowników \\
& - Nieprawidłowo sporządzona dokumentacja magazynowa \\
& - Nieprawidłowy przepływ informacji pomiędzy podmiotami łańcucha \\
& - Optymalizacja zapasów wyłącznie pod kątem jednego kryterium \\
\hline
\end{tabular}

Źródło: opracowanie własne.

\section{Ekologistyka w gospodarce magazynowej}

Globalizacja współczesnej gospodarki wywiera znaczącą presję na przedsiębiorstwa. Jej celem jest zwrócenie uwagi na logistyczne ujęcie zarządzania. Wiąże się to $\mathrm{z}$ usprawnieniem procesów w przedsiębiorstwie, takich jak zaopatrzenie, magazynowanie, dystrybucja oraz transport. Celem składowania zapasów jest możliwość ciągłości wykonywania zadań organizacji. Konieczność posiadania przez przedsiębiorstwo magazynów jest uwarunkowana różnicą w wielkości popytu i podaży, chęcią uniknięcia braków towarowych, wspomagania procesów produkcyjnych oraz względami ekonomicznymi.

Organizacja gospodarki magazynowej tworzy całokształt możliwości podejmowanych przedsięwzięć, które są stosowane podczas zarządzania magazynem. Celem jest koordynacja wszystkich funkcji magazynu i tym samym osiągnięcie jak najlepszych efektów przy minimalizacji pracy.

Przepływy wyrobów gotowych przez poszczególne ogniwa łańcucha dostaw należą do branży Fast Moving Consumer Goods ${ }^{5}$. Są to artykuły spożywcze, kosmetyki, detergenty, papierosy oraz alkohol. Towary należące do tej branży często są kupowane przez klientów, dlatego jest ona nazywana branżą towarów szybko rotujących. Większość artykułów z branży FMCG ma terminy ważności do spożycia, dlatego w logistyce istotna jest płynność przepływu ładunków przez łańcuchy dostaw, w celu niedopuszczenia do przeterminowania się artykułów ${ }^{6}$.

Na przestrzeni lat tematyka ekologii stawała się coraz bardziej istotna dla przedsiębiorstw. Przepisy prawne wskazują na konieczność odpowiedniego zarządzania

5 P. Miller, Analiza wpływu innowacyjnego narzędzia na wspomaganie działalności firm z branży FMCG na rynku, Wydawnictwo Uniwersytetu Łódzkiego, Łódź 2016, s. 350.

6 K. Liczmańska, Strategie marek produktowych na rynku FMCG, Wydawnictwo Naukowe Uniwersytetu Mikołaja Kopernika, Toruń 2016, s. 130. 
powstałymi odpadami na terenie magazynu. Również łańcuchy dostaw wywierają presję na przedsiębiorstwa w celu odpowiedniej ochrony środowiska naturalnego.

Dla zrównoważonego rozwoju istotne jest zagospodarowanie odpadów, czyli możliwość zaspokojenia potrzeb przyszłych pokoleń, lecz bez przekraczania granic, które będą mieć długoletni wpływ na ekosystem Ziemi. Ważnym elementem w gospodarce magazynowej odpadów jest odpowiednie przygotowanie magazynów pod kątem prawidłowego funkcjonowania. Dotyczy to następujących elementów:

- odpowiedniego wyposażenia magazynów pod względem: miejsca składowego (regałów), urządzeń transportowych, których celem jest zapewnienie odpowiednich warunków do składowania dóbr,

- prawidłowe zagospodarowanie towarów pochodzących ze zwrotu,

- prowadzenie selektywnej zbiórki odpadów.

Prawidłowe przygotowanie magazynu pod względem składowania dóbr przemieszczalnych stanowi podstawę prowadzenia gospodarki magazynowej bez zakłóceń. Niedopuszczenie do wystąpienia czynników ryzyka spowoduje zmniejszenie ilości dodatkowej pracy w magazynie i wykorzystania dodatkowych materiałów, a tym samym w mniejszym stopniu będzie oddziaływać negatywnie na środowisko naturalne gospodarki magazynowej.

\section{Podmioty badawcze ${ }^{7}$}

Aspekt wdrażania ekologistycznych elementów do procesu magazynowego jest oparty na analizie 30 podmiotów badawczych. Przedsiębiorstwa są podzielone na dwie grupy:

- przedsiębiorstwa świadczące usługi outsourcingu magazynowego (18 podmiotów),

- przedsiębiorstwa posiadające magazyn własny (12 podmiotów).

Badaniom podlegały przedsiębiorstwa świadczące usługi magazynowe, dysponujące:

- magazynami zmechanizowanymi,

- budynkami wysokiego składowania,

- obiektami posiadającymi od 15000 do 30000 miejsc paletowych,

- magazynami stosującymi kody kreskowe jako technikę automatycznej identyfikacji towarów.

7 Badania finansowane $z$ projektu badawczego Narodowego Centrum Nauki - projekt nr UMO-2012/05/B/HS4/04139. 
Wśród badanych podmiotów przeprowadzono audyt logistyczny. Na jego podstawie określono czynniki ryzyka w procesie magazynowym przedsiębiorstw. Następne wyłoniono grupy zakłóceń, w których mogą zostać wdrożone elementy ekologicznego zarządzania ryzykiem.

\section{Procedura zarządzania ryzykiem w procesie magazynowym}

Prawidłowe i efektywne funkcjonowanie procesu magazynowego poprzez eliminację czynników ryzyka jest najważniejszym elementem w gospodarce magazynowej. W tabeli 2 przedstawiono procedurę, jaką badane podmioty mogą wdrożyć do magazynów zmechanizowanych w celu ograniczenia negatywnego oddziaływania na środowisko naturalne.

Tabela 2. Procedura zarządzania ryzykiem w procesie magazynowym

\begin{tabular}{|c|c|}
\hline Czynnik ryzyka & Zarządzanie czynnikami ryzyka pod kątem ekologistycznym \\
\hline \multicolumn{2}{|r|}{ Uszkodzenie towaru wewnątrz magazynu } \\
\hline $\begin{array}{l}\text { - Uszkodzenie } \\
\text { towaru podczas } \\
\text { przyjęcia wyrobu } \\
\text { do magazynu } \\
\text { - Uszkodzenie } \\
\text { towaru podczas } \\
\text { magazynowania } \\
\text { - Nieprawidtowe } \\
\text { zabezpieczenie } \\
\text { towarów } \\
\text { składowanych } \\
\text { - Uszkodzenie } \\
\text { wyrobów podczas } \\
\text { załadunku } \\
\text { towarów } \\
\text { na środek } \\
\text { transportu } \\
\text { zewnętrznego }\end{array}$ & $\begin{array}{l}\text { Uszkodzony towar w magazynie należy podzielić na dwie kategorie: } \\
\text { zniszczone opakowanie i uszkodzony wyrób gotowy. W przypadku uszko- } \\
\text { dzenia opakowania w miarę możliwości, pod kątem jakościowym, należy } \\
\text { je naprawić. Produkty, które nie uległy całkowitemu zniszczeniu, mogą } \\
\text { zostać sprzedane na rynku wtórnym. Wyroby, które nie mogą zostać } \\
\text { sprzedane, należy poddać recyklingowi lub przekazać do utylizacji. } \\
\text { Istotnym elementem podczas roztadunku i załadunku towaru jest sama } \\
\text { paleta. Większość badanych podmiotów jest wyposażona w europalety, } \\
\text { które tatwo ulegają zniszczeniu. Palety, które nie nadają się do dalszej eks- } \\
\text { ploatacji, powinny zostać przekazane do recyklingu, jednakże elementy } \\
\text { z palety, które nie uległy zniszczeniu, powinny zostać w magazynie i pełnić } \\
\text { funkcję części zamiennych dla palet, które uległy drobnemu uszkodzeniu. } \\
\text { Warto również zainwestować w palety z innego materiału niż drewniane, } \\
\text { które są bardziej odporne na zniszczenie, np. aluminiowe lub plastikowe. } \\
\text { Wybrane wyroby gotowe (np. towary mające wysoką cenę) nale- } \\
\text { ży umieszczać w plastikowych skrzyniopaletach z pokrywą. W tym } \\
\text { przypadku nie będzie już konieczności stosowania dodatkowo palet } \\
\text { do transportu. Tak zabezpieczony towar będzie bezpieczny podczas za- } \\
\text { tadunku/rozładunku przez operatora wózka widtowego i w ten sposób } \\
\text { zostanie ograniczona ilość uszkodzonych dóbr w magazynie. } \\
\text { Organicznie ruchu pojazdów wewnątrz magazynu ma wiele plusów dla } \\
\text { przedsiębiorców. Głównym celem jest zredukowanie zużycia energii, zmniej- } \\
\text { szenie prawdopodobieństwa spowodowania wypadku przez operatora } \\
\text { wózka widłowego oraz zredukowanie ilości uszkodzonego towaru składo- } \\
\text { wanego w magazynie. Odpowiednie metody wydania towaru z magazynu, } \\
\text { zgodne z charakterystyką składowanych towarów (branż FMcG), to metody } \\
\text { FIFO (First In, First Out) lub FEFo (First Expired, First Out). }\end{array}$ \\
\hline & Otrzymanie uszkodzonego produktu \\
\hline
\end{tabular}




\begin{tabular}{|c|c|}
\hline Czynnik ryzyka & Zarządzanie czynnikami ryzyka pod kątem ekologistycznym \\
\hline $\begin{array}{l}\text { Otrzymanie } \\
\text { uszkodzonego } \\
\text { dobra }\end{array}$ & $\begin{array}{l}\text { Jeżeli otrzymany towar ma wadę, należy zgłosić to nadawcy towaru. } \\
\text { W porozumieniu z dostawcą powinna zostać podjęta próba naprawy } \\
\text { wyrobu, w szczególności jeśli uszkodzeniu uległo wyłącznie opakowa- } \\
\text { nie. W przypadku braku możliwości naprawy towar powinien zostać } \\
\text { zwrócony dostawcy. Nie należy wysyłać jednej uszkodzonej palety, lecz } \\
\text { po zebraniu odpowiedniej liczby palet wysłać całość towaru. Ten sche- } \\
\text { mat zniweluje tworzenie pustych przebiegów. }\end{array}$ \\
\hline \multicolumn{2}{|r|}{ Materiały zabezpieczające produkt i pełniące funkcję nośnika informacji } \\
\hline $\begin{array}{l}\text { Nieprawidłowe } \\
\text { oznakowanie } \\
\text { towarów } \\
\text { Nieodpowiednie } \\
\text { zabezpieczenie } \\
\text { wyrobu } \\
\text { składowanego }\end{array}$ & $\begin{array}{l}\text { Pudła, taśmy, przekładki transportowe, folia stretch do stabilizacji } \\
\text { i ochrony produktów na palecie to podstawowe materiały stosowa- } \\
\text { ne do ochrony zapasu. Jeżeli zastosowanie foli ma na celu wyłącznie } \\
\text { stabilizację produktu, można ją zastąpić pasem zabezpieczającym, } \\
\text { który jest produktem wielokrotnego użytku. Przedsiębiorstwa powinny } \\
\text { zainwestować w owijarkę - maszynę, której celem jest idealne nało- } \\
\text { żenie foli na paletę i mniejsze zużycie surowca. Pozostałe materiaty, } \\
\text { które w wyniku eksploatacji stały się odpadem, powinny być starannie } \\
\text { posegregowane. } \\
\text { Przedsiębiorcy powinni pamiętać o cyklicznych szkoleniach pracowni- } \\
\text { ków na temat ochrony towaru oraz prawidłowej identyfikacji wyrobu. } \\
\text { Wraz ze zmniejszającą się liczbą błędów, ilość używanych surowców } \\
\text { również się zmniejszy, będzie także powstawało mniej odpadów. } \\
\text { W badanych podmiotach stosowano kody kreskowe jako technikę } \\
\text { automatycznej identyfikacji towarów. W większości organizacji były uży- } \\
\text { wane etykiety papierowe. Ten rodzaj surowca tatwo ulega zniszczeniu, } \\
\text { a oderwanie etykiety z palety, która jest owinięta folią stretch, sprawia, } \\
\text { że konieczne jest ponowne użycie nowej foli w celu prawidłowego } \\
\text { zabezpieczenia towaru. Powoduje to potrzebę wykorzystania dodatko- } \\
\text { wego surowca oraz powstanie niepotrzebnego odpadu. }\end{array}$ \\
\hline \multicolumn{2}{|r|}{ Dokumentacja magazynowa } \\
\hline $\begin{array}{l}\text { - Przyjęcie } \\
\text { produktów } \\
\text { z niepełną lub } \\
\text { źle wypełnioną } \\
\text { dokumentacją } \\
\text { - Wydanie } \\
\text { nieprawidłowo } \\
\text { sporządzonej } \\
\text { dokumentacji } \\
\text { wysyłkowej } \\
\text { - Nieprawidtowo } \\
\text { sporządzona } \\
\text { dokumentacja } \\
\text { magazynowa }\end{array}$ & $\begin{array}{l}\text { Dokumentacja papierowa jest niezbędna do prawidłowego funkcjono- } \\
\text { wania tańcucha dostaw artykułów należących do branży FMCG. Atest } \\
\text { jakości, dokument CMR czy dokument wydania zewnętrznego muszą } \\
\text { zostać wydrukowane i zarchiwizowane. Jednakże wiele dokumentów, } \\
\text { w szczególności e-maili, nie musi być drukowanych. Podstawowe } \\
\text { elementy, takie jak drukowanie jedynie kartek zapełnionych tekstem, } \\
\text { stosowanie funkcji druku dwustronnego, regulacja marginesów, nie } \\
\text { spowodują zwiększenia prawdopodobieństwa wystąpienia czynnika } \\
\text { ryzyka związanego z dokumentacją magazynową, a w znaczny sposób } \\
\text { zminimalizują liczbę zużywanych kartek. }\end{array}$ \\
\hline
\end{tabular}


Tabela 2. (cd.)

\begin{tabular}{|c|c|}
\hline Czynnik ryzyka & Zarządzanie czynnikami ryzyka pod kątem ekologistycznym \\
\hline \multicolumn{2}{|r|}{ Stany magazynowe } \\
\hline $\begin{array}{l}\text { - Nieprawidłowe } \\
\text { określenie } \\
\text { terminu dostawy } \\
\text { - Zmniejszenie } \\
\text { liczby wydań } \\
\text { towaru } \\
\text { z magazynu } \\
\text { - Posiadanie } \\
\text { zapasów } \\
\text { zbędnych }\end{array}$ & $\begin{array}{l}\text { Niski poziom rotacji wyrobów powoduje powstanie zapasów zbędnych. } \\
\text { Na podstawie tych czynników ryzyka należy rozdzielić sposób postępo- } \\
\text { wania ze względu na rodzaj magazynu: } \\
\text { - magazyn outsourcingowy - informacja do producenta/właściciela } \\
\text { artykułów o posiadaniu dodatkowych palet wyrobów, nieujętych } \\
\text { w systemie komputerowym, } \\
\text { - magazyn własnościowy - zgłoszenie informacji do działu dystrybu- } \\
\text { cji o posiadaniu towarów zbędnych oraz o niskim poziomie rotacji } \\
\text { poszczególnych artykułów. }\end{array}$ \\
\hline
\end{tabular}

Źródło: opracowanie własne.

Zakłócenia występują na każdym etapie procesu magazynowego.

\section{Kostka ICOM w procesie magazynowym}

W procesie magazynowania występują liczne czynniki ryzyka. W tabeli 2 został dokonany ich podział ze względu na negatywne skutki, jakie ze sobą niosą. Dla każdej grupy zakłóceń wskazano sposoby zarządzania ryzykiem ze zwróceniem uwagi na aspekt ekologistyczny. W celu przedstawienia w formie graficznej procedur wdrażania zarządzania ryzykiem w sposób ekologistyczny w gospodarce magazynowej wyrobów gotowych została zastosowana metoda IDEF (Integration Definition $)^{8}$. Kostka ICOM zbudowana jest z prostokąta, za pomocą którego można przedstawić fragment funkcjonowania danego procesu. Na rysunku 1 za pomocą schematu ukazano budowę kostki ICOM.

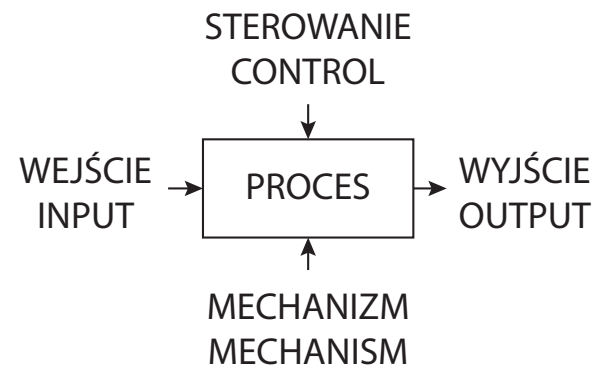

Rysunek 1. Kostka ICOM

Źródło: A. Ulan, J. Sitkowska, J. Duda, Wykorzystanie techniki IDEFO do graficznego przedstawienia procesu wytwarzania cementu, Oficyna Wydawnicza Polskiego Towarzystwa Zarządzania, Opole 2014, s. 1057.

8 A. Stawowy, A. Maciot, R. Wrona, Procesowy model zakładu odlewniczego, Komisja Odlewnictwa Polskiej Akademii Nauk Oddział w Katowicach, Kraków 2005, s. 279-286. 
Zastosowanie metody IDEF umożliwi prawidłowe zrozumienie procedury zarządzania ryzykiem wyrobów gotowych z branży FMCG, wzbogaconej o elementy ekologistyczne. Schematy opracowane zgodnie $z$ tą metodą są łatwiejsze do przyswojenia dla pracowników dzięki czytelności i przejrzystości. Graficzne przedstawienie zarządzania ryzykiem procesu magazynowego wzbogaconego o aspekt ekologistyczny zostało ukazane za pomocą kostki ICOM, wykorzystując metodę IDEF0 (rys. 2).

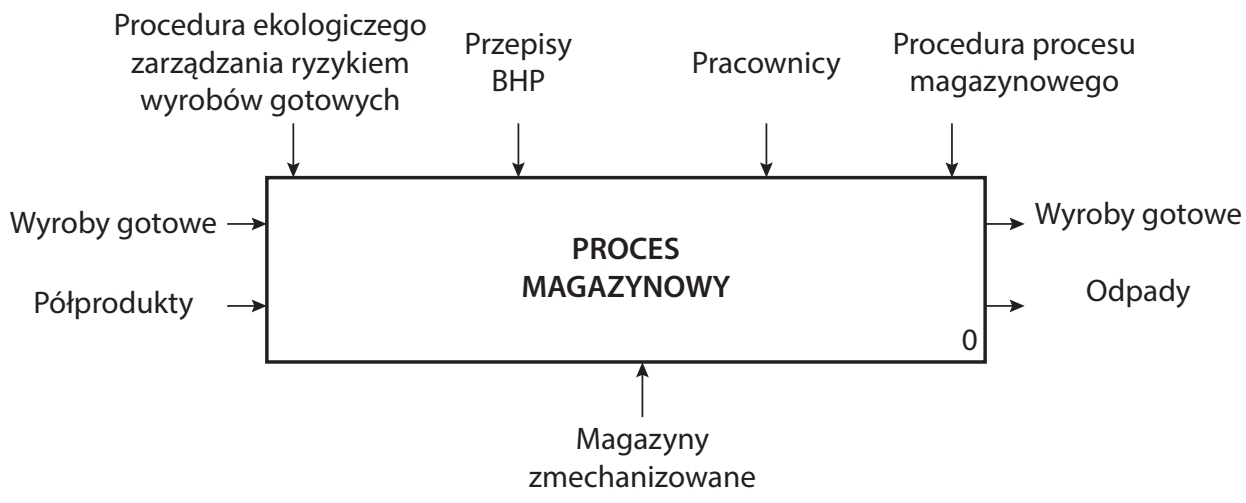

Rysunek 2. Kostka ICOM procesu magazynowego

Źródło: opracowanie własne.

Kostka ICOM przedstawia proces magazynowy produktów. Danymi wejściowymi dla procesu magazynowego jest wyrób gotowy z branży FMCG. Elementami wspomagającymi proces przyjęcia wyrobu do magazynu są półprodukty, których celem jest ochrona dóbr oraz pomoc w wykonywaniu czynności manipulacyjnych. Elementami wyjściowymi są wyroby gotowe oraz powstałe odpady - zarówno z półproduktów, jak i z wyrobów gotowych, które na jednym z etapów procesu magazynowego uległy uszkodzeniu i nie mogą zostać wysłane do kolejnego ogniwa łańcucha dostaw lub odbiorcy finalnego.

Segmentami sterującymi procesem magazynowym są:

- przepisy BHP w magazynie,

- pracownicy: stanowiska administracyjne oraz operatorzy magazynowi,

- procedura postępowania w procesie magazynowym,

- procedura ekologistycznego zarządzania ryzykiem wyrobów gotowych - zastosowanie procedur zapobiegawczych w celu niedopuszczenia do wystąpienia czynnika ryzyka oraz w przypadku wystąpienia zakłócenia łagodzenia jego negatywnych konsekwencji, wskazując na elementy związane z ekologią w celu prowadzenia działalności gospodarczej w zgodzie ze środowiskiem naturalnym. 
Mechanizm zastosowany w gospodarce magazynowej to wykorzystanie kodów kreskowych jako nośnika informacji, a praca jest wykonywana za pomocą wózków widłowych.

Rozwinięciem kostki ICOM jest blok A0 zawierający kilka kostek, tzw. kostki dzieci. Poszczególne kostki procesu magazynowego mają przypisane właściwe sobie numery w celu wskazania chronologii wykonywania działań. Poniżej znajduje się blok A0 (rysunek 3), za pomocą którego przedstawiono proces naprawczy uszkodzonego zapasu.

Blok A0 składa się z czterech kostek. Za pomocą mapy procesu ukazano mechanizmy naprawcze wyrobu w celu dalszego zbytu produktu. Kluczowymi elementami są kostki o numerach 3 i 4, w których została wdrożona procedura ekologistycznego zarządzania ryzykiem zgodnie z przedstawionymi w tabeli 2 mechanizmami. Uszkadzając towar w procesie magazynowym, badane podmioty nie będą mogły zrealizowanie zamówienia klienta, biorąc pod uwagę to, iż w magazynie nie ma wyrobów, którymi można by zastąpić dany produkt. Zobowiązania wobec klientów nie będą wykonane, zostaną więc złamane zasady umowy, które niejednokrotnie wiążą się z olbrzymimi karami finansowymi. Należy również mieć na uwadze koszty uszkodzonego towaru. Głównym celem łańcucha dostaw jest utrzymanie stałego przepływu produktów przez poszczególne jego ogniwa - od producenta, przez przedsiębiorstwa świadczące usługi magazynowe, aż do odbiorcy ostatecznego.

Elementy, które będą naprawiane zgodnie z procedurą ekologistycznego zarządzania ryzykiem badanych podmiotów, to:

- opakowanie zewnętrzne wyrobu,

- poszczególne części wyrobów gotowych (wymiana lub naprawa),

- zabezpieczenia ochronne produktów (wzmocnienie).

Zgodnie ze wdrażaną procedurą po czynnościach naprawczych produkt będzie podlegał badaniom pod kątem jakości. Kontrola jest bardzo ważnym elementem nie tylko w procesie produkcji, lecz również podczas magazynowania wyrobów. To w tym miejscu towar znajduje się najdłużej w przedsiębiorstwie i jego jakość na przestrzeni czasu może ulec zmianie.

Kostka A0 pełni funkcję kostki „rodzica” dla kostki niższego rzędu A2, będącej kostką „dzieckiem”. Na rysunku 4 przedstawiono mapę procesu A2. 
Aspekty ekologistycznego zarządzania ryzykiem w gospodarce magazynowej...

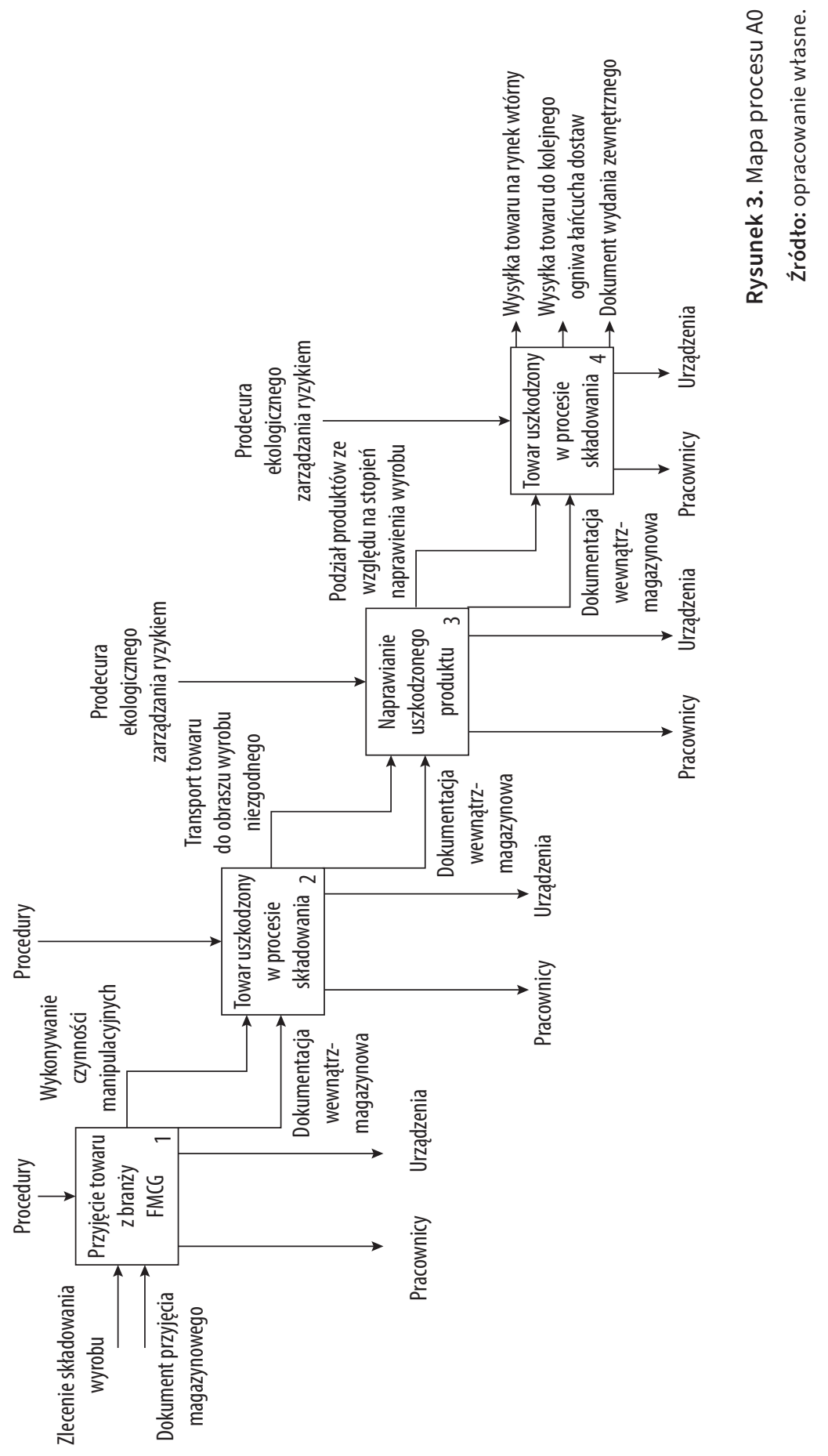




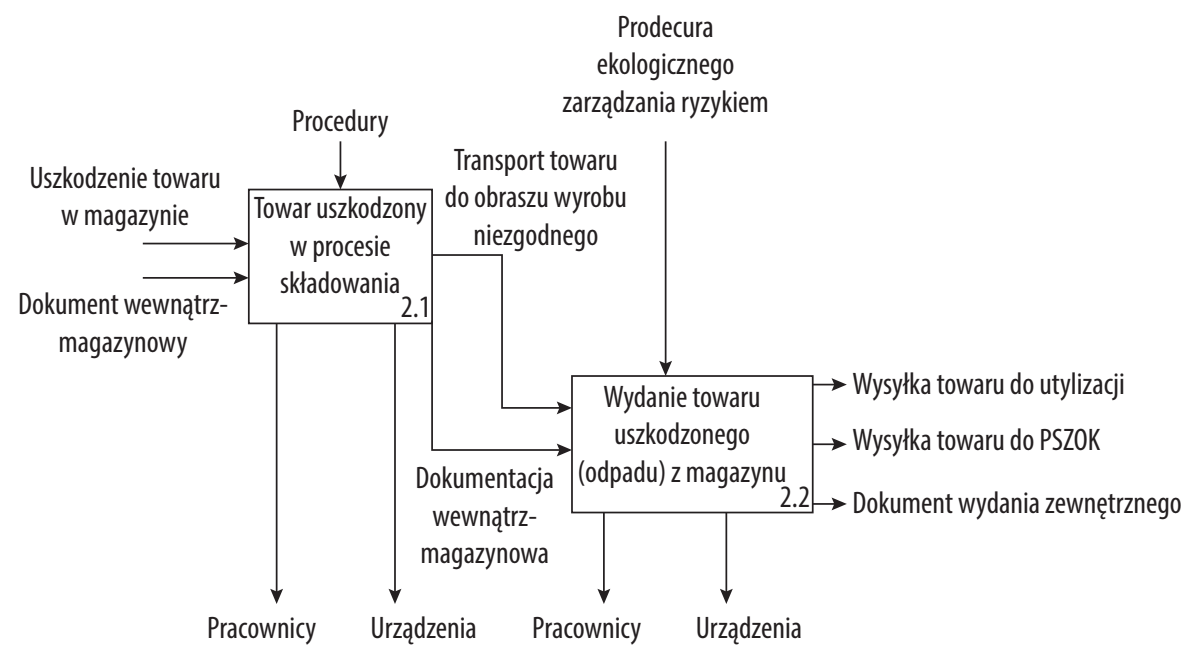

Rysunek 4. Mapa procesu A2

Źródto: opracowanie własne.

Mapa procesu A2 jest zbudowana z dwóch kostek i ukazuje inne postępowanie z uszkodzonym wyrobem, niż przedstawiono na mapie procesu A0. Mapa procesu prezentuje sytuację braku możliwości zastosowania metody naprawczej wyrobu. Występuje wtedy konieczność prawidłowego zagospodarowania powstałego $\mathrm{w}$ procesie magazynowania odpadu. Ten krok w procedurze ekologicznego zarządzania ryzykiem w procesie magazynowym jest podrzędną metodą zarządzania czynnikami ryzyka, ponieważ powstaje odpad w gospodarce magazynowej. Towar nienadający się do wysyłki do kolejnego ogniwa łańcucha dostaw musi zostać przetransportowany do obszaru wyrobu niezgodnego na terenie magazynu, gdzie będzie składowany do czasu wydania wyrobu na zewnątrz. Zgodnie z procedurą wyroby powinny być wydawane do utylizacji, na przykład do gospodarstw wiejskich (gdzie uszkodzony artykuł spożywczy pełnić będzie funkcję paszy dla zwierząt) lub do Punktu Selektywnej Zbiórki Odpadów Komunalnych.

\section{Zakończenie}

Głównym problemem w ekologistyce gospodarki magazynowej są powstające podczas składowania dóbr odpady z wyrobów gotowych. Na podstawie przeprowadzonego audytu logistycznego w badanych podmiotach określono czynniki ryzyka występujące w procesie magazynowym. Zebrane dane stanowiły podstawę do opracowania ekologistycznych procedur zarządzania ryzykiem w gospodarce magazynowej. Schemat działania przedsiębiorstw zgodnie z zalecanymi elementami 
ma na celu zminimalizowanie powstawania odpadów, a także prawidłową ochronę składowanych zapasów oraz wskazanie na produkty, które mogą stać się zasobem do wykorzystania w innej formie. $Z$ perspektywy prawidłowo funkcjonującego procesu magazynowego uszkodzenie towaru jest najgroźniejsze dla organizacji. Jest to związane z licznymi konsekwencjami, między innymi brakiem możliwości realizacji zlecenia klienta czy kosztami finansowymi utraconego dobra.

Aby prawidłowo wprowadzić ekologiczną procedurę zarządzania ryzykiem dla badanych podmiotów, jako metodologię badawczą zastosowano mapowanie ryzyka, czyli kostkę ICOM. Celem zastosowania tej metody jest ukazanie w sposób chronologiczny oraz przejrzysty etapów, jakie należy podjąć, aby nie dopuścić do wystąpienia czynników ryzyka, oraz wskazanie elementów, w których można w mniejszy sposób negatywnie oddziaływać na środowisko naturalne. Za pomocą mapy procesu ukazano wszystkie elementy, z jakich musi się składać prawidłowo wykonany proces magazynowy, uwzględniający aspekty ekologistyczne, czyli elementy wejściowe i wyjściowe, zastosowane mechanizmy oraz segment sterowniczy. Zarządzając poszczególnymi czynnikami ryzyka w procesie magazynowym, należy pamiętać o ekologii. Opracowane odpowiednio procedury zarządzania ryzykiem wskazują przedsiębiorstwom, że głównym celem jest nadal zabezpieczenie magazynowanego dobra, jednak można również realnie wpłynąć na ochronę środowiska naturalnego, nie obniżając efektywności procesu magazynowego, a wręcz usprawniając gospodarkę magazynową.

Bibliografia

Galińska B., Gospodarka magazynowa, Wydawnictwo Difin, Warszawa 2016.

Kaczmarek T., Zarzqdzanie ryzykiem. Ujęcie interdyscyplinarne, Wydawnictwo Difin, Warszawa 2010.

Kulińska E., Aksjologiczny wymiar zarzq̨dzania ryzykiem procesów logistycznych. Modele i eksperymenty ekonomiczne, Oficyna Wydawnicza Politechniki Opolskiej, Opole 2011.

Kulińska E., Parametryzacja kosztów ryzyka procesów logistycznych, Wydawnictwo PLACET, Warszawa 2015.

Miller P., Analiza wpływu innowacyjnego narzędzia na wspomaganie działalności firm z branży FMCG na rynku, Wydawnictwo Uniwersytetu Łódzkiego, Łódź 2016.

Liczmańska K., Strategie marek produktowych na rynku FMCG, Wydawnictwo Naukowe Uniwersytetu Mikołaja Kopernika, Toruń 2016.

Stawowy A., Macioł A., Wrona R., Procesowy model zakładu odlewniczego, Komisja Odlewnictwa Polskiej Akademii Nauk Oddziat w Katowicach, Kraków 2005.

Ulan A., Sitkowska J., Duda J., Wykorzystanie techniki IDEFO do graficznego przedstawienia procesu wytwarzania cementu, Oficyna Wydawnicza Polskiego Towarzystwa Zarządzania, Opole 2014. 


\section{Streszczenie}

Współczesna gospodarka magazynowa nie może wyłącznie opierać się na ochronie składowanych wyrobów. Musi również zostać wzbogacona o elementy chroniące środowisko naturalne. Celem artykułu jest ukazanie aspektu ekologistycznego zarządzania ryzykiem w logistycznym procesie magazynowania wyrobów gotowych z branży Fast Moving Consumer Goods. W badaniach zostały określone poszczególne czynniki ryzyka procesu magazynowego. Wskazano metody przeciwdziałania wystąpieniu danego czynnika ryzyka, chroniąc przy tym środowisko naturalne. Zastosowana w artykule metodologia badawcza to kostka ICOM. Za jej pomocą rozpoznano ryzyka mogące wystąpić w procesie magazynowym oraz wskazano wszystkie elementy mające wpływ na dany proces.

Wdrożenie zmian w funkcjonowanie procesu magazynowego wpłynie znacząco na środowisko naturalne oraz przyniesie przedsiębiorstwom magazynowym wiele korzyści, w tym oszczędności finansowe oraz zasobowe.

Słowa kluczowe: ekologistyka w procesie magazynowym, zarządzanie ryzykiem, kostka ICOM

\section{Aspects of ecologistic risk management in the warehouse of finished goods in the FMCG industry}

\section{Abstract}

Modern warehouse management can't be based solely on the protection of stored products. It must be also enriched with elements protecting the natural environment. The aim of the article is the environmental aspect of risk management in the logistics process of storing finished products from the Fast Moving Consumer Goods industry. The research identified specific risk factors for the warehouse process. Methods of preventing the occurrence of a given risk factor have been indicated, while protecting the natural environment. The research methodology used in the article is ICOM cubes. Using this method, the risks that may occur in the warehouse process were identified and all elements influencing the given process are indicated.

The implementation of changes in the operation of the warehouse process will significantly affect the natural environment and bring many benefits to warehouse companies, including financial and resource savings.

Keywords: ecologistic in the warehouse process, risk management, ICOM cube

Paweł Derek ${ }^{9}$

9 Mgr Pawet Derek - Uniwersytet Ekonomiczny we Wrocławiu, Katedra Strategii i Metod Zarządzania. 